\title{
TOXIC EFFECTS OF FORMALDEHYDE ON CELLULAR IMMUNITY AND POSSIBLE RELATIONSHIP TO ITS RISK OF CARCINOGENESIS: AN EXPERIMENTAL STUDY
}

\author{
Samah, A. El-Nagdy ${ }^{1}$, Ebtesam Elgezawy $^{2}$, Khalid Ali Nasif ${ }^{3}$ \\ ${ }^{1}$ Department of Forensic Medicine and Clinical Toxicology, Faculty of Medicine, Zagazig University \\ ${ }^{2}$ Clinical Pathology Department, Faculty of Medicine, Assiut University , ${ }^{3}$ Medical Biochemistry \\ Department, Faculty of Medicine, Minia University
}

\begin{abstract}
Corresponding Author:
Samah A. El-Nagdy

Department of Forensic

Medicine and Clinical

Toxicology, Faculty of

Medicine, Zagazig

University, Zagazig, Egypt

E-mail address:

elnagdysamah@yahoo.com
\end{abstract}

\section{INTRODUCTION}

Key words: Formaldehyde, spleen, Comet assay, lymphocytes, IL-10, IFN- $\gamma$

\section{ABSTRACT} effects which may be related to its risk of carcinogenesis.
F ormaldehyde (FA) is used in many industries including wood processing, construction and carpeting. Possible household exposure to FA from furniture made of plywood and particleboard can occur. Moreover, Itis used as a disinfectant and antiseptic in many human medicines, cosmotics and veterinary drugs (Salthammer et al., 2010).

Formaldehyde is a well- known established preservative for cadavers in anatomy departments with anatomy stuffs and students are exposed to that chemical. Also,
Exposure to formaldehyde (FA) can occurs either in the environment or in workplaces due to its common use in laboratory, industry, household and cosmotic products. This study was carried out to assess toxic effects of subacute exposure to FA on immune system in adult male albino rats and possible relationship to its risk of carcinogenesis. Methods: Fifty adult male albino rats were used for 28 days as follow: Group I: (20 rats) subdivided equally into group Ia negative control and group Ib positive control, Formaldehyde group: (30 rats) divided equally into groups II, III \& IV received FA by oral gavage at doses of 20, 40 and $80 \mathrm{mg} / \mathrm{kg}$ respectively. At the end of the study, spleen of each rat was dissected and subjected to histopathological examination, immunohistochemical staining for CD4+ and comet assay. Blood samples were withdrawn and used for evaluation of T-lymphocytes subsets (CD3+, CD4+ and CD8+), CD19+ B-lymphocytes and CD56+ natural killer (NK) cells by flow cytome analysis and cytokines profiles of interleukin 10 (IL-10) \& assay detected DNA damage in splenocytes of FA group. There were decrease in group IV. Assessment of cytokines detected a significant increase in IL-10 in all FA-treated rats, while IFN- $\gamma$ was decreased in groups III \& IV. Conclusion: Formaldehyde exposure resulted in dose-dependent immunotoxic

histopathology workers and other biological researchers are using $\mathrm{FA}$ and are liable to dangers of continuous exposure to that chemical (Raja \& Sultana, 2012).

Moreover, FA is included in many hair straightening products. Pierce et al. (2011) stated possible exposure of salon workers and clients to levels of FA greater than those restricted by occupational exposure limits even with the use of hair smoothing products marked as" free of formaldehyde".

FA may also be illegaly added as a preservative to food especially diaryproducts as 
cheese, yogurt, milk which can cause serious health problems. Although use of formaldehyde use in industries is allowed at percentages ranging from $3 \%$ to $4 \%$, its use is completely prohibited in food manufacture according to Food and Agricultural Organization Of The United Nations and WHO (Shahadat et al., 2016).

Cellular immunity includes $\mathrm{T}$ lymphocytes, B-lymphocytes and NK cells. Total T-lymphocytes (CD3+), T-helper cells (CD4+) and cytotoxic T cells (CD8+) are called T-lymphocytes subsets. CD4+ cells are subdivided according to their selective cytokines synthesis into $\mathrm{T}$ helper 1 cells which release mainly IFN- $\gamma$ and $\mathrm{T}$ helper 2 cells which release IL-10 (Starr et al., 2003).

Lymphocytes present in many organs with the most important are spleen, lymph nodes and blood. Spleen receive about 5\% $10 \%$ of cardiac output and contain about $15 \%$ of lymphocytes which reflects the importance of this organ in cell-mediated immunity (Cesta, 2006). Balance of immune system and subsequent balance of cytokines production is essential. When this balance is disturbed, health problems including risk of carcinogenesis can occur (Chokkalingam et al., 2013).

Interleukin-10 (IL-10) was found to inhibit many functions of the immune system including inhibition of macrophages and antigen expression which explain its crucial role in developing and promoting some tumors (Shankar and Genhong, 2012). High levels of IL-10 were detected in patients with various types of malignancies (Baniyash, 2006). On the other hand, role of interferon gamma (IFN$\gamma)$ in prevention of tumor development has been identified (Ikeda et al., 2002).

Comet Assay is a method of single cell gel electrophoresis (SCGE) assay to detect DNA damage in any tissue of all mammalians. Response of Comet assay can be used as an indicator of carcinogen exposure (Bowman et al., 2012).

Relationship between formaldehyde exposure and toxic effects on immune system with subsequent relationship to its risk of carcinogenesis is believed. Formaldehyde was categorized as a carcinogenic chemical by International Agency for Research on Cancer (IARC) which stated that a strong but not confirmed relationship is assumed between exposure to FA and leukemia (Zhang et al., 2010).

This work was carried out to evaluate possible toxic effects of FA on cellular immunity through assessment of $\mathrm{T}$ lymphocytes subsets, B- lymphocytes and NK cells distributions with evaluation of IL-10 and IFN- $\gamma$ cytokines profiles in blood of adult male albino rats. Also histopathological examination of spleen, immunohisto-chemistry for CD4+ and Comet assay of splenocytes were studied

\section{MATERIALS \& METHODS \\ II.1. Materials:}

II.1.1. Chemical: Formaldehyde solution (37 $\%$; Sigma-Aldrich Co., Saint Louis, USA). It was administered on a weight/volume basis to the experimental rats.

\section{II.1.2. Experimental animals:}

Fifty adult male albino rats weighing 180-220 gram provided by Animal House of Faculty Of Medicine, Zagazig University were used in this experiment. All the animals were apparently healthy and all ethically approved conditions used for animal housing \& handling were considered. Standards for animal care and administration met those acquired by applicable international laws and regulations. Standard laboratory animal feed $\&$ water were given. The animals were accommodated to the environmental conditions before beginning of study for one week. The duration of the study was 28 days (subacute toxicity). The rats were divided as follow:

- Group I: 20 rats subdivided equally into group Ia negative control which did not receive any medications and group Ib positive control received distilled water daily by oral gavage.

- Formaldehyde group: : Included 30 rats divided equally into groups II, III \& IV received FA by oral gavage at doses of 20, 40 and $80 \mathrm{mg} / \mathrm{kg}$ respectively. These doses are 
equivalent to $1 / 40,1 / 20$ and $1 / 10$ of the 800 $\mathrm{mg} / \mathrm{kg}$ oral LD50 of formaldehyde in rats (Tsuchiya et al., 1975 and WHO, 1996).

\section{II.2. Methods:}

Blood samples were collected from medial canthus of the eyes according to Renwick (1989) at the end of the experiment for assessment of Tlymphocyte subsets, B-lymphocytes and NK cells and for cytokines IL-10 \& IFN- $\gamma$ measurement. The methods used included the following:

\section{II.2.1. Flow cytometric analysis of blood lymphocytes subsets:}

Two ml of blood were collected from each rat in EDTA tube for flow cytometric analysis of blood lymphocytes population using a set of fluorochrome-labeled monoclonal antibodies against surface and intracellular markers. This was performed at Flow Cytometry Unit, Clincal Pathology Department, Assuit University Hospitals as follow:

-100 ul of blood was taken from each sample and incubated with an amount of $20 \mathrm{ul}$ of various monoclonal antibodies in the dark for $20 \mathrm{~min}$. at $4^{\circ} \mathrm{C}$. Then, a lysing solution was used for lysis of RBCs followed by washing with phosphate buffered saline (PBS).

-Monoclonal antibodies used for enumerating different T-lymphocytes populations included the following; Peridinium-chlorophyll-protein (Per-CP) conjugated $\mathrm{CD} 3+$ purchased from (Becton Dickinson, Bioscience, USA), fluoro isothiocyanate (FITC) conjugated CD4+ (Becton Dickinson, Bioscience, USA) and phycoerythrin (PE) conjugated CD8+ (Becton Dickinson, Bioscience, USA). For assessment of B-lymphocytes, the antibody used was phycoerythrin (PE) conjugated CD19 supplied by ((Becton Dickinson, Bioscience, USA). Natural killer cells (NK) were enumerated using fluoro isothiocyanate (FITC) conjugated CD56 (Becton Dickinson, Bioscience, USA).

-An isotype-matched negative control was prepared for each sample with a forward and side scatter histogram was used to determine lymphocytes subsets (R1).
-The absolute counts of CD3+, CD4+, CD8+, CD19+ subsets of lymphocytes and CD56+ natural killer cells were calculated.

-The analysis was carried out by the help of fluorescence-activated cell sorter aided by software of CellQUEST (FACSCaliber, Becton Dickinson, USA).

\section{II.2.2. Cytokines measurement:}

At the end of the study, $2 \mathrm{ml}$ of blood were obtained from each rat, then centrifuged for 15 min. The serum samples were stored at $-70{ }^{\circ} \mathrm{C}$ for cytokines assessment. Interleukin-10 (IL10) and interferon- $\gamma($ IFN- $\gamma$ ) were measured in the serum according to manufacturer technique using Rat IL-10 ELISA Kit and Rat IFN gamma ELISA Kit supplied by (Abcam, USA) . The assay were performed using wells coated with antibodies specific for IL-10 and IFN- $\gamma$ as follow:

- $100 \mathrm{ul}$ of the samples were added to the wells which allowed IL-10 and IFN- $\gamma$ to bind the antibodies fixed to them.

- Then, biotinylated anti-IL-10 and anti- IFN- $\gamma$ provided with the kits were further added followed by washing to get rid of the biotinylated antibodies not bound to IL-10 and IFN- $\gamma$.

- An enzyme reaction produced by streptavidinperoxidase enzyme induced a colour agent which intensity correlated to IL-10 and IFN- $\gamma$ concentrations in the sample.

II.2.3. Histopathological examination of spleen:

Formalin-fixed, paraffin-embedded $5 \mu \mathrm{m}$ thick sections were prepared and stained with hematoxylin and eosin (H\&E) for histopathological examination of spleen (Suvarna et al. 2013).

\section{II.2.4. Immunohistochemical staining for CD4 in spleen:}

Immunohistochemistry for CD4 in spleen was performed using CD4+ antibodies (Dako Carpinteria, USA). Section of formalinfixed, paraffin-embedded (3-4 $\mu \mathrm{m}$ thick) spleen tissues were prepared then transferred to glass slides coated with aminopropyltriethoxysilane. Anti-CD4+ antibodies were then added to the 
sections followed by incubation for $60 \mathrm{~min}$. at room temperature. Sections were stained with hematoxylin and dehydrated with ethanol and xylene. Immunostaining of CD4 were carried out by counting expression of CD4 on lymphocytes at 40x magnification (EL-Sheikh et al., 2016).

\section{II.2.5. Comet Assay of spleen:}

Comet assay was performed according to the method described by Singh et al. (1988). Tail lengths were measured from the middle of the nucleus to the end of the tail. Visualization of DNA damage was done using 40x objective on a fluorescent microscope. Komet 5 image analysis software was used for image analysis (Liverpool, UK). It was attached to a CCD camera for qualitative and quantitative assessment of DNA damage with calculation of tail moment.

\section{II.2.6. Statistical Analysis}

Results were expressed as mean \pm standard deviation (SD). Multigroup comparisons of the means were carried out by one way analysis of variance (ANOVA) test. Least significant difference (LSD) test was used to compare the difference between the experimental groups. Chi-square test was used for comparing descriptive data. The statistical significance difference for all tests was set at $\mathrm{P}<0.05$.

\section{RESULTS}

No statistically significant difference was found between group $1 \mathrm{a}$ and group $1 \mathrm{~b}$ regarding the studied parameters, so group 1a was used as the control group for comparison with FA treated groups.

\section{III.1. Blood lymphocytes subsets:}

A significant decrease in all $\mathrm{T}$ lymphocytes subsets (CD3+, CD4+ and CD8+) was found in groups III and IV when compared with group I (control group) $(\mathrm{p}<0.05)$ (Table 1 \& Fig. 2,3 ), while no significant difference was detected between group II received the least dose of FA and group I ( $p>0.05$ ) (Table 1, Fig. 1). On the other hand, A significant increase in CD19+ count was observed in groups III and IV as compared with group I $(\mathrm{p}<0.05)$ (Table 2 $\&$ Fig. 2,3) with no significant difference was found between group II and group I ( $p>0.05$ ) (Table $2 \&$ Fig.1). Only group IV showed a significant decrease in number of CD56+ when compared with group I $(\mathrm{P}<0.05)$ (Table $2 \&$ Fig.3) with no significant difference was detected on comparing groups II \& III with group I (P>0.05) ( Table 2, Fig. 1, 2).

Table (1): Statistical analysis of blood T-lymphocytes subsets (CD3+,CD4+ \&CD8+) (cells/ul) assessed by flow cytometry in the studied groups using ANOVA test.

\begin{tabular}{|c|c|c|c|c|c|c|}
\hline \multirow{2}{*}{$\begin{array}{l}\text { T lymphocytes } \\
\text { subset (cells/ul } \\
\text { blood) }\end{array}$} & \multicolumn{4}{|c|}{ Groups } & \multicolumn{2}{|c|}{ ANOVA test } \\
\hline & $\begin{array}{c}\text { Group I } \\
\text { (Control) } \\
\mathrm{N}=10\end{array}$ & $\begin{array}{c}\text { Group II } \\
\mathrm{N}=10\end{array}$ & $\begin{array}{l}\text { Group III } \\
\mathrm{N}=10\end{array}$ & $\begin{array}{c}\text { Group IV } \\
\mathrm{N}=10\end{array}$ & $\mathrm{~F}$ & $\mathrm{P}$ \\
\hline CD3+ & $\begin{array}{c}8532.44 \pm 53 \\
1.61\end{array}$ & $8321.42 \pm 642.42$ & $\begin{array}{c}7816.56 \pm 615 \\
.62^{\mathrm{ab}}\end{array}$ & $6514.26 \pm 521.92^{\mathrm{abc}}$ & 21.92 & $0.000 *$ \\
\hline CD4+ & $\begin{array}{c}7043.82 \pm 69 \\
2.36\end{array}$ & $6834.56 \pm 564.24$ & $\begin{array}{c}6012.98 \pm 594 \\
.54^{\mathrm{ab}}\end{array}$ & $5019.56 \pm 390.41^{\mathrm{abc}}$ & 25.97 & $0.000^{*}$ \\
\hline CD8+ & $\begin{array}{c}2164.86 \pm 25 \\
4.62\end{array}$ & $1964.34 \pm 201.49$ & $\begin{array}{c}1624.59 \pm 94 \\
32^{\mathrm{a}}\end{array}$ & $1321.91 \pm 164.91^{\mathrm{abc}}$ & 36.18 & $0.000 *$ \\
\hline
\end{tabular}

F: ANOVA $\quad \mathrm{N}$ : Number of rats in each group

*: Significant

LSD for repeated measure ANOVA expressed as symbols ${ }^{a}$ Significant as compared to group I, ${ }^{b}$ Significant compared to group II and ${ }^{\mathrm{c}}$ Significant compared to group III. 
Table (2): Statistical analysis of B-lymphocytes (CD19+) and natural killer cells (NK CD56+) in blood (cells/ul) assessed by flow cytometry analysis in the studied groups using ANOVA test.

\begin{tabular}{|c|c|c|c|c|c|c|}
\hline & $\begin{array}{c}\text { Group I } \\
\text { Control) } \\
\text { N=10 }\end{array}$ & $\begin{array}{c}\text { Group II } \\
\mathbf{N = 1 0}\end{array}$ & $\begin{array}{c}\text { Group III } \\
\mathbf{N = 1 0}\end{array}$ & $\begin{array}{c}\text { Group IV } \\
\mathbf{N}=10\end{array}$ & F & P \\
\hline $\begin{array}{c}\text { CD19+ } \\
\text { (cells/ul } \\
\text { blood) }\end{array}$ & $7342.23 \pm 1752.76$ & $7425.46 \pm 1572.55$ & $8645.24 \pm 1845.11^{\text {a,b }}$ & $9822.56 \pm 1523.59^{\text {a,b }}$ & 4.87 & $0.01^{*}$ \\
\hline $\begin{array}{c}\text { CD56+ } \\
\text { (cells/ul } \\
\text { blood) }\end{array}$ & $2152.43 \pm 950.56$ & $2264.52 \pm 837.19$ & $2045.56 \pm 546.46$ & $1056.42 \pm 634.99^{\text {a,b,c }}$ & 14.34 & $0.000^{*}$ \\
\hline
\end{tabular}
F: ANOVA
$\mathrm{N}$ : Number of rats in each group
*: Significant

LSD for repeated measure ANOVA expressed as symbols ${ }^{a}$ Significant as compared to group I, ${ }^{b}$ Significant compared to group II and ${ }^{\mathrm{c}}$ Significant compared to group III.
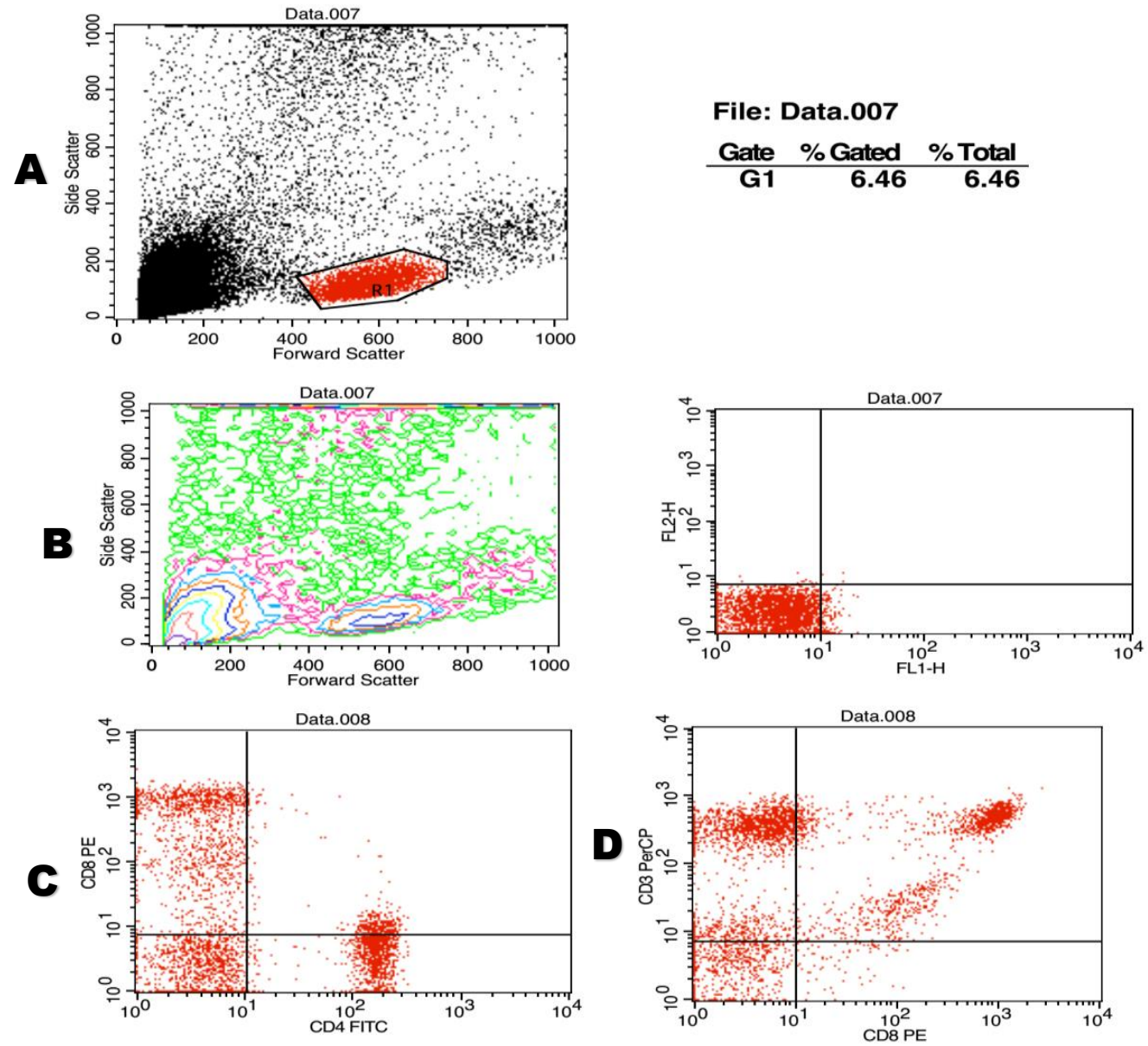

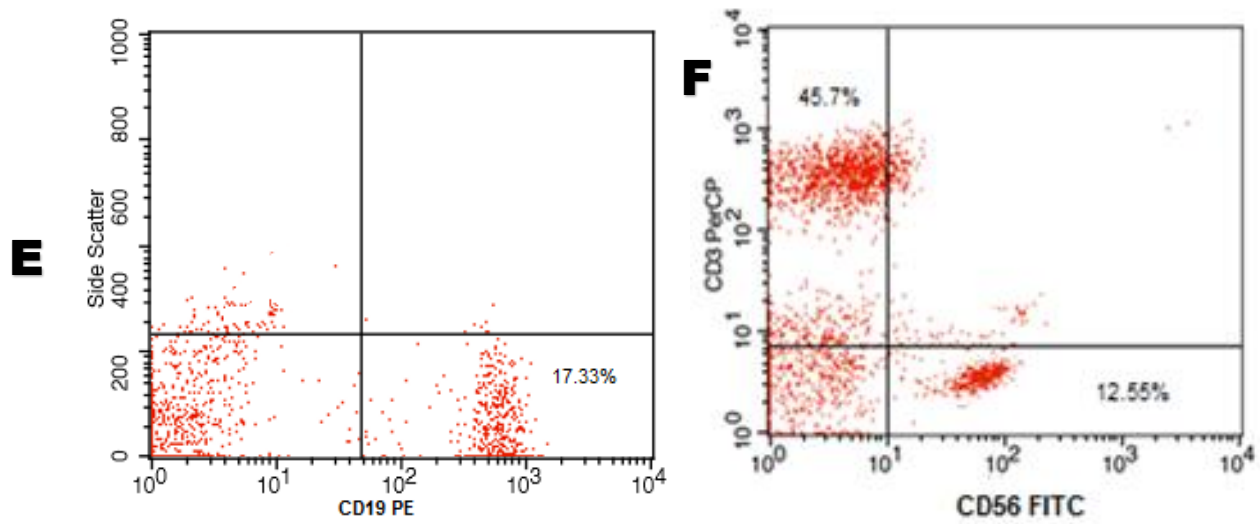

Fig. (1): Group I \& group II: Lymphocyte gating \& analysis by flow cytometer A) Forward scatter, side scatter of peripheral blood R (Gated lymphocytes). B) Isotype control to exclude non-specific background staining and lymphocyte gating. C) Expression of CD4+ \& CD8+ of lymphocytes in the "R1" region. D) Expression of CD3+ \& CD8+ of lymphocytes in the "R1" region. E) Expression of CD19+of lymphocytes in the "R1" region. F) Expression of CD 56+ of lymphocytes in the "R1" region.
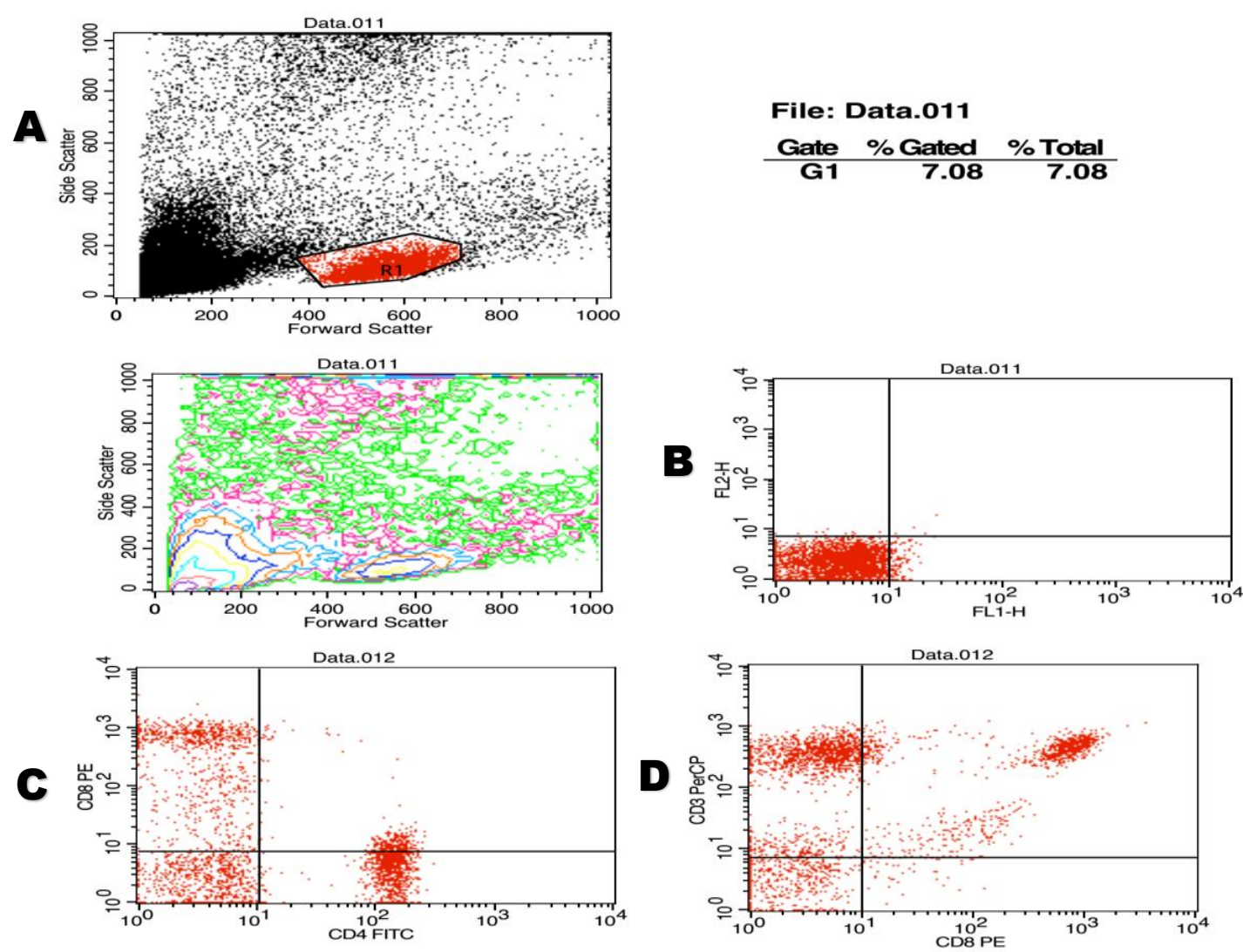

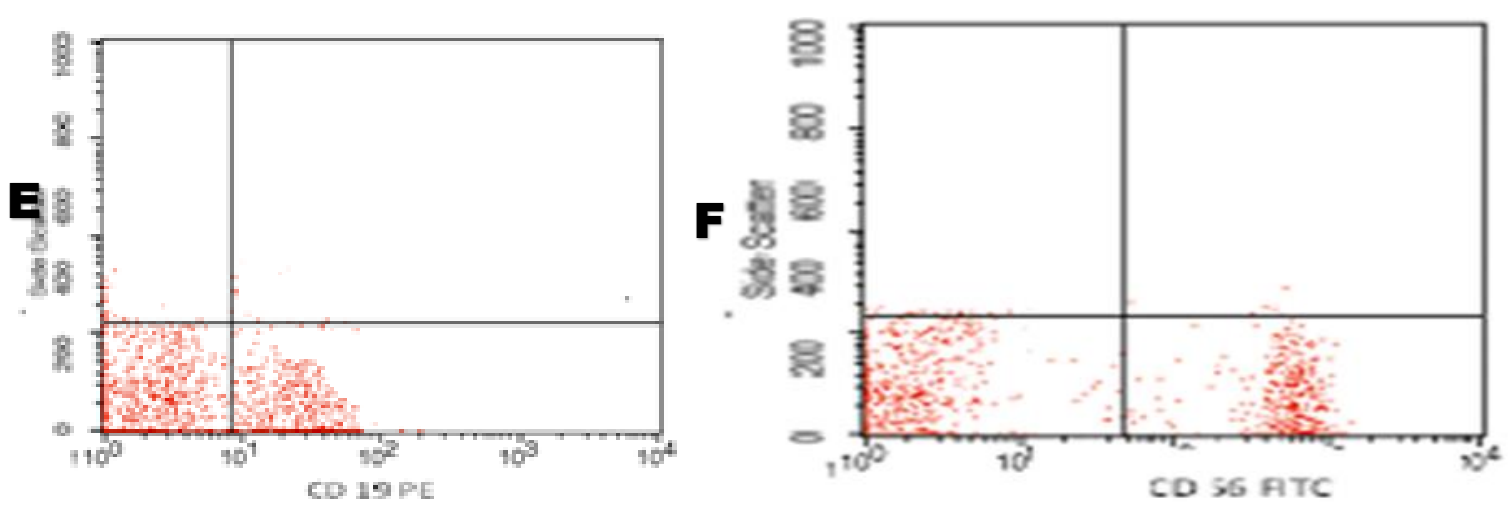

Fig. (2): Group III: Lymphocyte gating \& analysis by flow cytometer A) Forward scatter, side scatter of peripheral blood R (Gated lymphocytes). B) Isotype control to exclude non-specific background staining and lymphocyte gating. C) Decreased expression of CD4+ \& CD8+ of lymphocytes in the "R1" region. D) Decreased expression of $\mathrm{CD} 3+\& \mathrm{CD} 8+$ of lymphocytes in the "R1" region. E) increased expression of CD19+of lymphocytes in the "R1" region. F) normal expression of CD 56+ of lymphocytes in the "R1" region. 

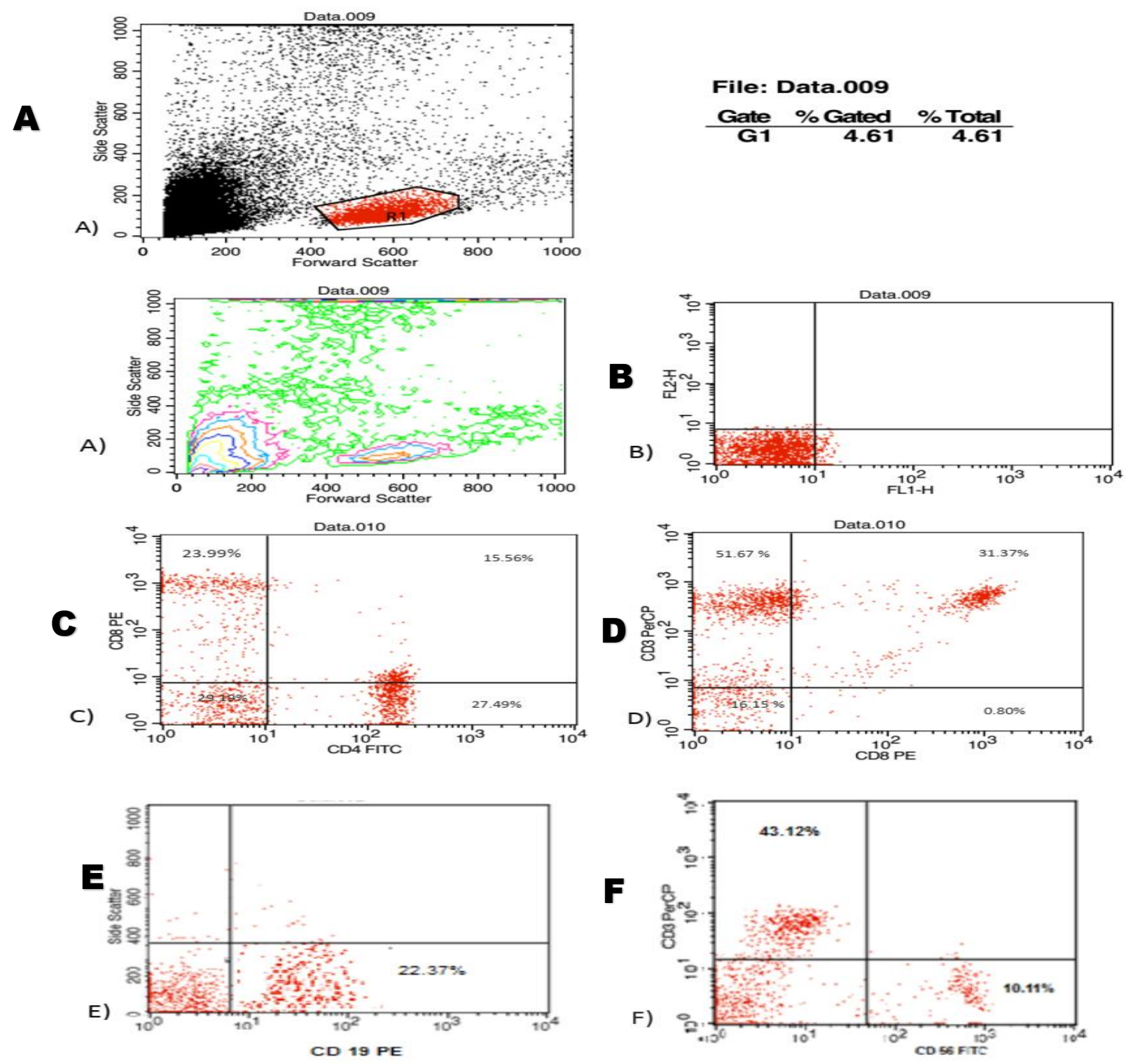

Fig. (3): Group IV: Lymphocyte gating \& analysis by flow cytometer A) Forward scatter, side scatter of peripheral blood R (Gated lymphocytes). B) Isotype control to exclude non-specific background staining and lymphocyte gating. C) Decreased expression of CD4+ \& CD8+ of lymphocytes in the "R1" region. D) Decreased expression of CD3+ \& CD8+ of lymphocytes in the "R1" region. E) increased expression of CD19+of lymphocytes in the "R1" region. F) Decreased expression of CD 56+ of lymphocytes in the "R1" region.

\section{III.2 Cytokines profile:}

Regarding cytokines profile assessed in this study, IL-10 was significantly increased in all FA groups on comparison with control group ( $\mathrm{p}<0.05)$ (Table 3). The most increase was observed in group IV which received the highest dose of FA $(80 \mathrm{mg} / \mathrm{kg})$ followed by groups III and II. When IFN- $\gamma$ was evaluated in the studied groups, a significant decrease was detected in groups III and IV when compared with group I $(\mathrm{P}<0.05)$ (Table 3) with no significant difference was found between groups II and group I ( $\mathrm{P}>0.05)$ (Table 3$)$. 
Table (3): Statistical analysis of interleukin-10 (IL-10) and interferon gamma (IFN- $\gamma$ ) in serum $(\mathrm{pg} / \mathrm{ml})$ assessed by ELISA in the studied groups using ANOVA test.

\begin{tabular}{|c|c|c|c|c|c|c|}
\hline & $\begin{array}{c}\text { Group I } \\
\text { (Control)N=10 }\end{array}$ & $\begin{array}{c}\text { Group II } \\
\mathrm{N}=10\end{array}$ & $\begin{array}{c}\text { Group III } \\
\text { N=10 }\end{array}$ & $\begin{array}{c}\text { Group IV } \\
\mathrm{N}=10\end{array}$ & F & $\mathbf{P}$ \\
\hline $\begin{array}{c}\text { IL-10 } \\
(\mathrm{pg} / \mathrm{ml})\end{array}$ & $534.94 \pm 46.23$ & $620.91 \pm 40.51^{\mathrm{a}}$ & $722.92 \pm 55.53^{\mathrm{a}, \mathrm{b}}$ & $760.42 \pm 47.76^{\mathrm{a}, \mathrm{b}}$ & 45.52 & $000^{*}$ \\
\hline $\begin{array}{c}\text { IFN- } \gamma \\
(\mathrm{pg} / \mathrm{ml})\end{array}$ & $52.24 \pm 2.31$ & $48.56 \pm 1.91$ & $41.67 \pm 2.75^{\mathrm{a}, \mathrm{b}}$ & $38.94 \pm 3.17^{\mathrm{a}, \mathrm{b}}$ & 63.31 & $000^{*}$ \\
\hline F: ANOVA & $\mathrm{N}: \mathrm{Nur}$ & nber of rats in ea & ch group & $\begin{array}{l}* \text { : Significant } \\
\text { as compared to gr }\end{array}$ & & \\
\hline
\end{tabular}

III.3. Histopathological examination of spleen:

Negative and positive control groups showed normal spleen with white and red pulps. The white pulp consisted of well circumscribed lymphoid follicles containing large number of lymphocytes. The red pulp included splenic cords which are branching and anastomosing with sinusoids in between (Fig.4). FA treated rats showed disruption of splenic architecture, decrease in the size and cellular component of lymphocytes follicles with indistinct discrimination between red and white pulp and congestion of sinusoids (Fig.4).
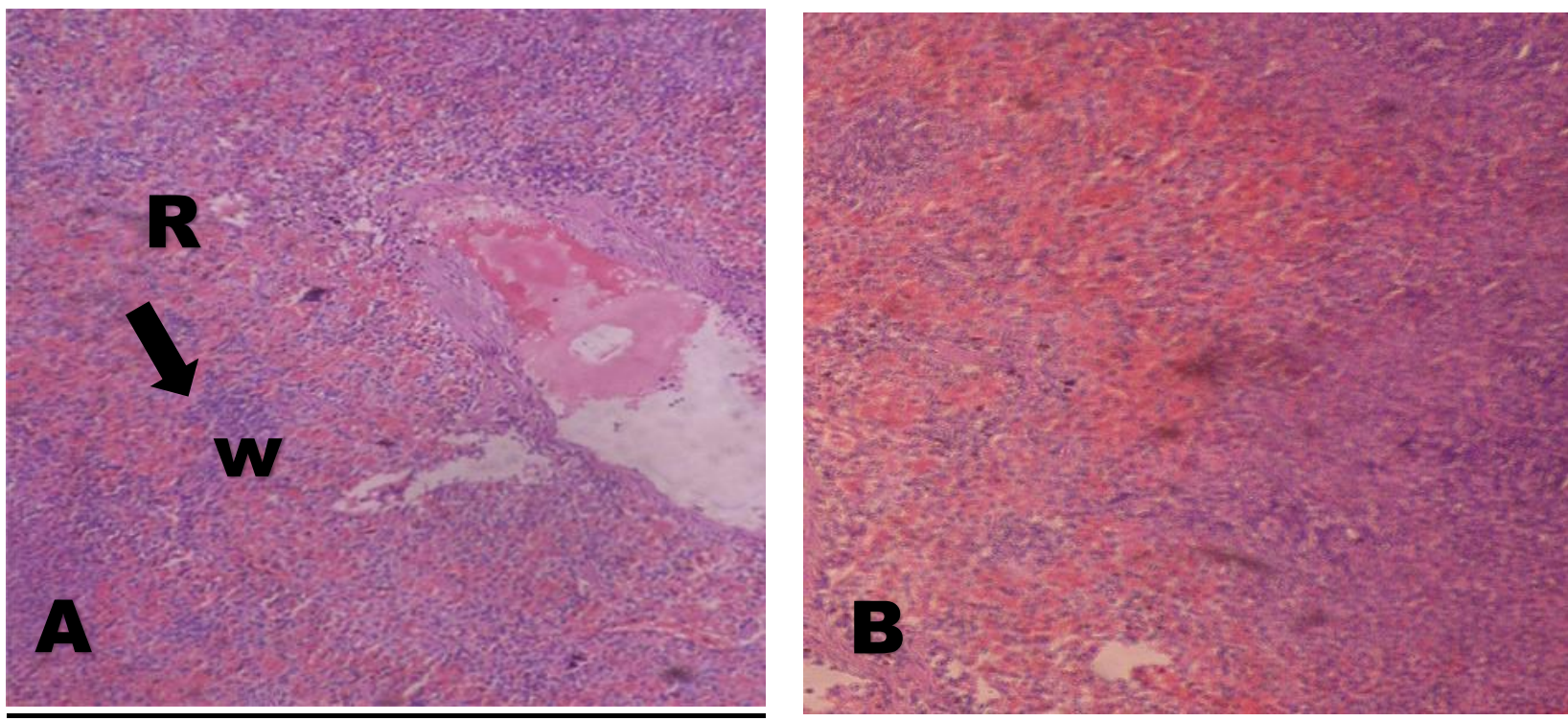

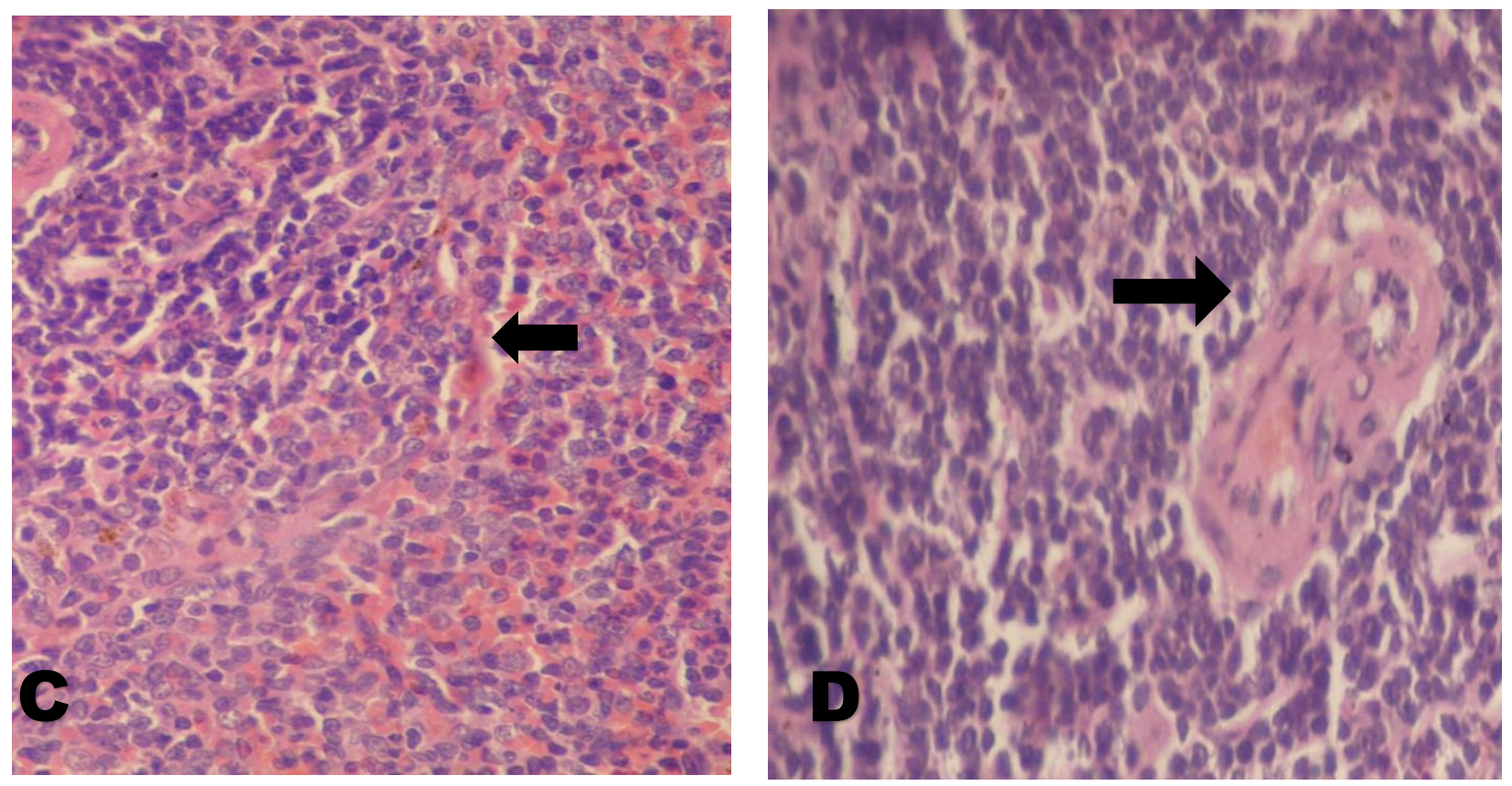

Fig. (4): A photomicrograph of sections in spleen of adult male albino rats of the studied groups. (A) Group I showing normal architecture of spleen with white pulp (W) and red pulp (R) with well-defined marginal zone (arrow). (B) group II showed disturbed spleen architecture with decrease of size and cellular component of lymphocytes follicles. (C) group III showing sinusoids packed with RBCs (arrow). (D) Group IV showing congested blood sinusoids. (Images magnification, A, B 100 X\& C, D 400X).

\section{III.4. Immunohistochemical staining for CD4+:}

There was a significant decrease in CD4+ immunoreaction in spleen of FA groups when compared with control group and this effect was dose dependent with the least CD4+ expression was found in group IV received the highest dose of formaldehyde.
CD4+ immunohistochemical staining appeared as positive brownish membranous immunoreaction of lymphocytes (Table 4 \& Fig.5).

Table (4): Statistical analysis of CD4+ immunoreaction in spleen lymphocytes in the studied groups using Chi square test.

\begin{tabular}{|c|c|c|c|c|c|c|c|c|c|c|}
\hline Groups & \multicolumn{2}{|c|}{$\begin{array}{l}\text { Group I } \\
\text { (Control) }\end{array}$} & \multicolumn{2}{|c|}{ Group II } & \multicolumn{2}{|c|}{ Group III } & \multicolumn{2}{|c|}{ Group IV } & \multicolumn{2}{|c|}{ Total } \\
\hline & \multicolumn{2}{|c|}{$\mathrm{N}=10$} & \multicolumn{2}{|c|}{$\mathrm{N}=10$} & \multicolumn{2}{|c|}{$\mathrm{N}=10$} & \multicolumn{2}{|c|}{$\mathrm{N}=10$} & & \\
\hline $\begin{array}{c}\text { CD4+ } \\
\text { immunoreaction }\end{array}$ & No & $\%$ & No & $\%$ & No & $\%$ & No & $\%$ & No & $\%$ \\
\hline$+(1-25$ cell $)$ & 1 & 10 & 4 & 40 & 5 & 50 & 7 & 70 & 17 & 42.5 \\
\hline$++(26-50$ cell $)$ & 2 & 20 & 3 & 30 & 4 & 40 & 2 & 20 & 11 & 27.5 \\
\hline$+++(\geq 50 \%)$ & 7 & 70 & 3 & 30 & 1 & 10 & 1 & 10 & 12 & 30 \\
\hline Total & 10 & 100 & 10 & 100 & 10 & 100 & 10 & 100 & 40 & 100 \\
\hline$\chi^{2}$ & & & & & & & & & & \\
\hline $\mathrm{p}$ & & & & & & & & & & \\
\hline
\end{tabular}

$$
\chi^{2}=\text { Chi square } \quad \mathrm{p}<0.05 \text { : significant } \quad \mathrm{N}=\text { number of rats in each group }
$$




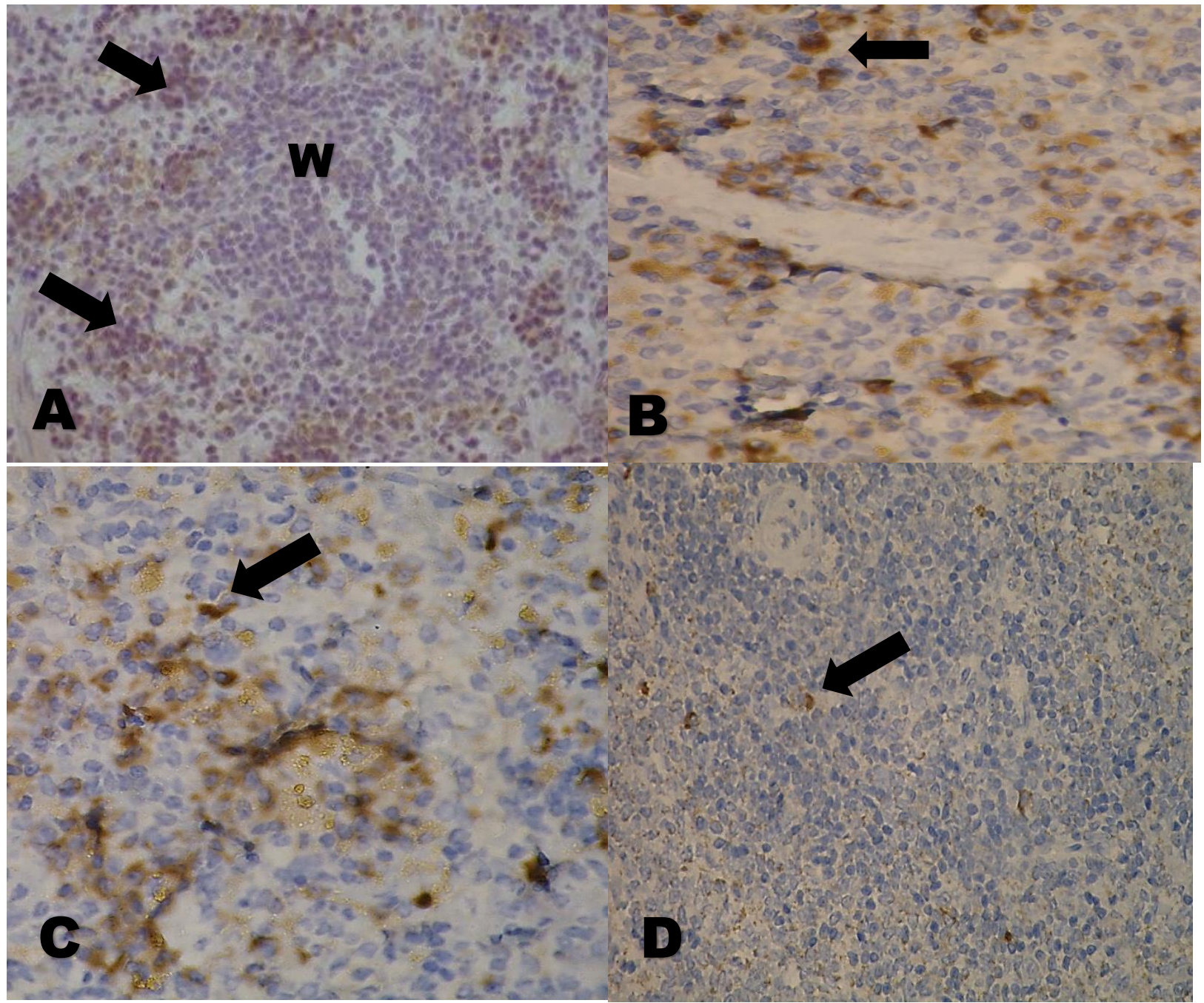

Fig. (5) showing Immunohistochemical staining of Spleen for CD4+. (A) Control group showing many brown positive immunoreactions for CD4+ in T-lymphocytes (arrow) around the white pulp (W). (B\&C): Groups II and III showed decreased expression of CD4+ grade ++ (arrow). (D): Group IV showed decrease in CD4+immunoreaction grade + (arrow). (Images magnification, A, D, $100 \mathrm{X} \& \mathrm{~B}, \mathrm{C} 400 \mathrm{X}$ ).

\section{III.5. Comet Assay of spleen:}

DNA damage was observed in the rats exposed to FA in the form of increased tail length and percentage of tail moment when compared to the control group $(\mathrm{p}<0.05)$. It was dose-dependent with group IV exhibited the most severe DNA damage (Table 5, Fig.6). 
Table (5): Statistical analysis of Comet assay parameters in the studied groups using ANOVA test.

\begin{tabular}{|l|l|l|l|l|}
\hline Groups & $\begin{array}{l}\text { Tail length } \\
(\mu \mathrm{m})\end{array}$ & $\begin{array}{l}\text { Tail } \\
\text { moment }\end{array}$ & $\begin{array}{l}\text { Tail length } \\
\text { distribution } \\
(\boldsymbol{\mu m})\end{array}$ & $\begin{array}{l}\text { Tail moment } \\
\text { distribution }\end{array}$ \\
\hline Group I (Control) & $12.5 \pm 1.5$ & $10.8 \pm 1.2$ & $7.2 \pm 14.7$ & $5.8 \pm 13.6$ \\
\hline Group II & $27.3 \pm 8.5^{\mathrm{a}}$ & $36.1 \pm 16.5^{\mathrm{a}}$ & $10.5 \pm 74.2^{\mathrm{a}}$ & $8.2 .4 \pm 8.1^{\mathrm{a}}$ \\
\hline Group III & $33.6 \pm 1.1^{\mathrm{ab}}$ & $44 \pm 4.9^{\mathrm{ab}}$ & $17 \pm 6.3^{\mathrm{ab}}$ & $12.4 \pm 7.8^{\mathrm{ab}}$ \\
\hline Group IV & $47.7 \pm 1.7^{\mathrm{abc}}$ & $59 \pm 7.2^{\mathrm{abc}}$ & $19.8 \pm 7.8^{\mathrm{abc}}$ & $16.7 \pm 3.2^{\mathrm{abc}}$ \\
\hline F & 12.98 & 18.77 & 20.11 & 16.8 \\
\hline P & $0.000^{*}$ & $0.001^{*}$ & $0.000^{*}$ & $0.001^{*}$ \\
\hline
\end{tabular}

\section{F: ANOVA}

$\mathrm{N}$ : Number of rats in each group.

*: Significant

LSD for repeated measure ANOVA expressed as symbols ${ }^{\text {a }}$ Significant as compared to group I, ${ }^{b}$ Significant compared to group II and ${ }^{\mathrm{c}}$ Significant compared to group III.
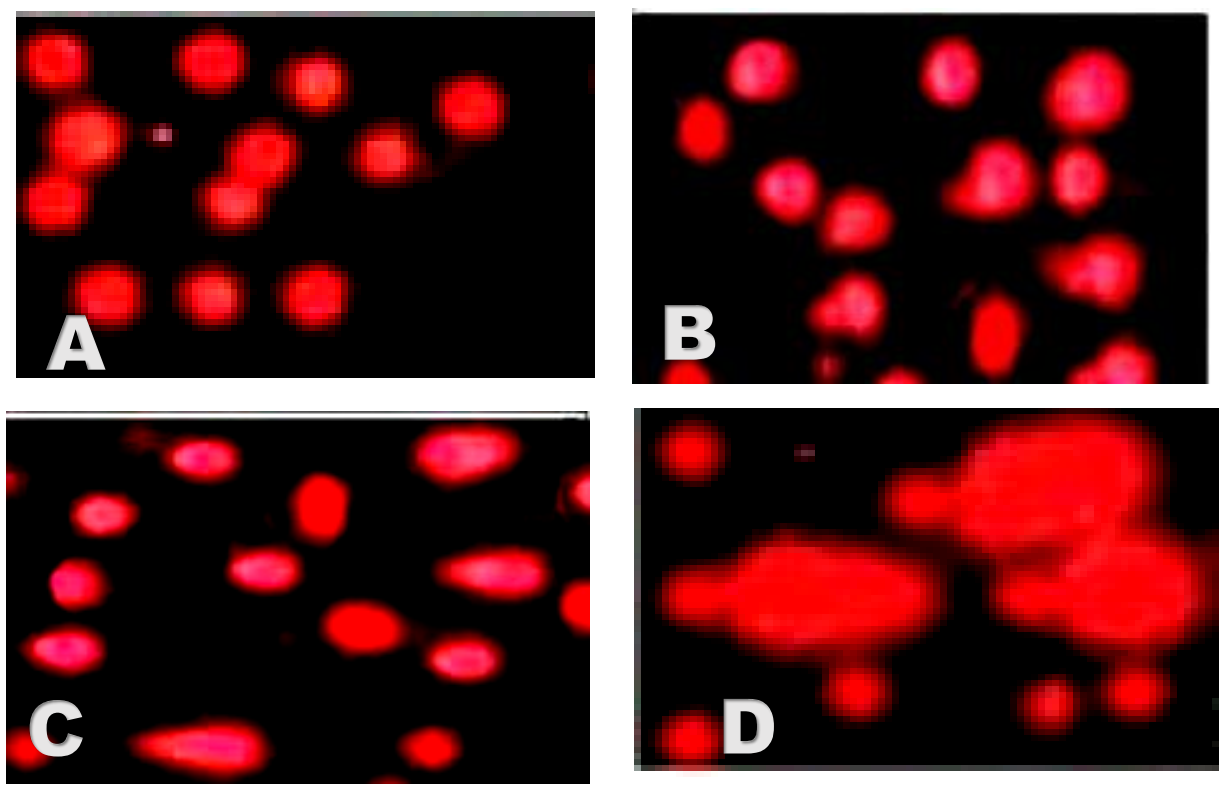

Fig. (6): Comet Assay of spleen cells (A) Control group showing intact nuclei (no DNA damage). $(\mathrm{B}, \mathrm{C}, \mathrm{D})$ formaldehyde treated groups showing various degree of DNA damage in splenocytes.

\section{DISCUSSION}

Formaldehyde (FA) is commonly used in many industrial and medical settings. Exposure to FA can result in a wide range of health hazards depending on duration and route of exposure (Kim et al., 2011). There are concerns about health adverse effects of FA on immune system and its risk of carcinogenesis. Unfortunately, many studies are inconsistent and limited information are available making it necessary to carry out more researches about immunotoxic effects of formaldehyde (Beane Freeman et al., 2009).

Balance of immune system and cytokines production is very important to avoid several health hazards including immune diseases and malignancy (Abdul Kalam et al., 2018). It was found that abnormal level of IL10 can modulate anti- tumor host immune response. Role of IL-10 has been determined by many studies in hematological malignancies including lymphomas, and myelomas (Holladay et al., 2010 \& Alexandrakis et al., 2015). 
Some studies were conducted in a trial to assess possible association of exposure to FA and alteration in immune response. It is hypothesized that FA exposure leads to toxic effects on immune system with alteration of cellular immunity represented by $\mathrm{T}$ cells, B cells and NK cells which in turn may cause abnormal immune response. Also, some cytokines produced by these cells are believed to be crucially incorporated in abnormal immune response (Bann et al., 2009).

Spleen is considered one of the most important organs involved in the immunological response. It is responsible for filtration of pathogens and foreign antigens including abnormal cells. These functions are mediated mainly through T\& B lymphocytes (Steven et al., 2019).

This work aimed to evaluate the toxic effects of FA on different immune system cells and certain cytokines which are supposed to be incorporated in abnormal immune response together with histopathological examination of spleen, immunohistochemistry for CD4+ expression of $\mathrm{T}$ lymphocytes and Comet assay of splenocytes.

The present work studied $\mathrm{T}$ lymphocytes subsets, B lymphocytes, NK cells and also cytokine profiles of IL-10 and IFN- $\gamma$ in blood of adult male albino rats exposed to FA. It was observed that FA-treated rats showed a decrease in T-lymphocytes subsets when compared with control while, B-lymphocytes were increased especially in high dose exposed rat. Regarding, NK cells, only group IV received the highest dose of FA $(80 \mathrm{mg} / \mathrm{kg})$ revealed significant decrease in NK cells count with respect to control group. Administration of FA resulted also in alteration in cytokine profile with an increase in IL-10 and decrease in IFN- $\gamma$ which was dose-dependent.

Histopathological examination of spleen in rats exposed to FA revealed disturbed spleen architecture with a significant reduction in the size and cellular components of lymphocytes follicles with distortion of the marginal zone between white and red pulps. Also, blood sinusoids of spleen were congested especially with high doses of FA.

Immunohistochemical staining for CD4+ expression on lymphocytes in spleen revealed a significant decrease in $\mathrm{CD} 4+$ immunoreaction in FA groups which was dosedependent reflecting affection of spleen functions as an important organ for production of lymphocytes including CD4+ T helper cells.

Comet assay was used to assess possible DNA damage due to formaldehyde exposure and various degrees of DNA damage were detected with more severe damage found in group IV exposed to the highest dose of FA.

In consistent with the results of this study, Hosgood et al. (2013) carried out a study on workers exposed to FA which revealed decrease in the counts of CD4+, CD8+ and natural killer $(\mathrm{NK})$ cells in the workers when compared with unexposed ones.

A study carried out by Ye et al. (2005) demonstrated decreased count of lymphocytes, especially CD8+ subset in FA-exposed workers. Also, Zhang et al. (2010) investigated workers exposed to formaldehyde for 1 year and detected a significant decrease in total lymphocytes which included CD4+ and CD8+ .

Another study concluded that occupational exposure to $\mathrm{FA}$ resulted in an increase in the count of $\mathrm{B}$ cells with a decrease in CD3+ T-lymphocytes and CD8+ cells with no changes were reported in $\mathrm{CD} 4+$ cells (Ye et al., 2005).

An experimental study carried out by Vargova et al. (1993) in which male rats had been exposed to a high dose of FA showed an increase in monocytes, RBCs and hemoglobin with decrease in lymphocytes counts. Regarding The result of this study with respect to NK cells, it coincided with that of Li et al. (2013) who reported a decrease in NK cells in a dose-dependent manner on exposure to FA.

On the other hand, the findings of NK cells were opposite to that of Aydin et al. (2013) who conducted a study to evaluate immune alteration in workers of wood processing exposed to FA levels accepted by 
Scientific Committee for Occupational Exposure Limits (SCOEL) which is $0.2 \mathrm{ppm}$ for 8 hours. They reported an increase in NK cells in those workers when compared with control.

Additionally, Xiaowei et al. (2014) studied the toxic effect of low and high formaldehyde exposure on immune system and reported an increase in B cells in all workers exposed to FA, while NK cells increased only with low exposure and no changes were detected regarding T-lymphocytes subsets.

These results were opposite to that of Aydin et al. (2013) who stated that workers exposed to FA at a mean work duration of $7.3 \pm$ 0.8 years and a mean concentration of $0.20 \pm$ $0.06 \mathrm{ppm}$, demonstrated a significant increase in absolute numbers of T-lymphocytes.

Haiyan et al., 2014 mentioned that this conflicting effect of FA on T-lymphocytes may be attributed to different FA exposure levels and times. At the end, FA is assumed to affect T-lymphocytes and subsequently immune response

Regarding cytokines, the findings of this work were in parallel with that of Ohtsuka et al. (2003) who found that exposure to FA by inhalation resulted in significant decrease in IFN- $\gamma$. Also, Haiyan et al. (2014) studied the effect of FA ( 0.5 and $20 \mathrm{mg} / \mathrm{kg}$ intraperitonial) on mice for 1 week and 1 month and recorded reduced levels of IFN- $\gamma$. They explained that by increased level of IL-10 which is a proven inhibitor of T-helper 1 cells cytokines including IFN- $\gamma$. Sasaki et al. (2009) also suggested that FA may promote T-helper 2 cytokines with suppression of IFN- $\gamma$.

The results of this work were also in accordance with that of Golalipour et al. (2008) and Monfared et al. (2013) who found abnormalities in spleen structure on exposure to FA represented by decrease in the number of lymphocytes populations with subsequent immunosuppression. A study carried out by Abd-Elhakim et al. (2016) included evaluation of toxic effects of formaldehyde on spleen revealed areas of necrosis in the splenic parenchyma together with alteration of the immunological parameters.

DNA damage in splenocytes detected by Comet assay in this study was in parallel with Orsiere et al. (2006) who stated that FA exposure resulted in chromosomal damage in human peripheral blood with increased frequency of micronucleated lymphocytes in workers occupationally exposed to FA which were supposed to be due to chromosomal loss and mitotic abnormalities.

Also, Gomaa et al. (2012) studied the genotoxic effects of $\mathrm{FA}$ both in rats and workers occupationally exposed to FA and concluded that FA resulted in DNA damage proven by Comet assay in the form of increased tail length and moment in bone marrow of rats and in blood lymphocytes of the workers. Kawanishi et al. (2014) studied the molecular basis for possible genotoxicity and carcinogenicity of FA and detected induction of hydroxymethyl mono-adducts on adenine, guanine and cytosine together with methylene crosslinks in DNA.

\section{CONCLUSION}

Formaldehyde exposure may cause immunotoxic effects in the form of altered cellular immunity including $\mathrm{T}$ lymphocytes, $\mathrm{B}$ lymphocytes and NK cells with improper cytokines production. This was accompanied by disturbed spleen structure with reduction in lymphocytes follicles, decreased expression for CD4+ as a marker for $\mathrm{T}$ lymphocytes with evident DNA damage of splenocytes as detected by Comet assay. Since healthy immune system recognizes and destroy nascent tumor cells, altered immune function together with DNA damage could participate in risk of FA exposure- induced cancer and this can explain the epidemiologic data supporting a causal relationship between FA exposure and malignancy.

\section{RECOMMENDATIONS}

-Restriction to FA level and time exposure limit which is equivalent to occupational exposure limits (OEL) 
- Strict prohibition of formaldehyde use as a food preservative.

- Further studies on the toxicological effects of FA on immune-response and possible relationship to its risk of carcinogenesis in exposed populations.

\section{REFERENCES}

Abul Kalam A.; Manobendro S. and Dan V. (2018): Immunomodulatory Effects of Probiotics on Cytokine Profiles. Biomed Res Int. Volume 2018, Article ID 8063647, 10 pages. doi.org/10.1155/2018/8063647.

Alexandrakis, M.; Goulidaki, N.; Pappa, CA; Boula, A.; Psarakis, F.; Neonakis, I. and Tsirakis, G. (2015): Interleukin-10 Induces Both Plasma Cell Proliferation and Angiogenesis in Multiple Myeloma. Pathol Oncol Res. (4):929-34. doi: 10.1007/s12253-015-9921-z.

Aydin, S.; Canpinar, H.; Undeger, U.; Guc, D.; Colakoglu, M.; et al. (2013): Assessment of immunotoxicity and genotoxicity in workers exposed to low concentrations of formaldehyde. Arch Toxicol 87: 145-153. doi: 10.1007/s00204012-0961-9.

Baan, R.; Grosse, Y.; Straif, K.; Secretan, B.; Bouvard, V.; Benbrahim-Tallaa, L.; Guha, N.; Freeman, C.; Galichet, L. and Cogliano, V. (2009): A review of human carcinogens--Part F: chemical agents and related occupations. Lancet Oncol.; 10:1143-1144.

Baniyash, M. (2006): Chronic inflammation, immunosuppression and cancer: new insights and outlook. Semin Cancer Biol.; 16(1):80-8.

Beane Freeman, L.E.; Blair, A.; Lubin, J.H.; Stewart, P.A.; Hayes, R.B.; Hoover, R.N. and Hauptmann, M. (2009): Mortality from lymphohematopoietic malignancies among workers in formaldehyde industries: the National Cancer Institute Cohort. J Natl Cancer Inst. 20;101(10):751-61. doi: 10.1093/jnci/djp096.

Bowman, L.; Castranova, V. and Ding, M. (2012): Single cell gel electrophoresis assay (comet assay) for evaluating nanoparticles-induced DNA damage in cells. Methods Mol Biol. 2012;906:415-22. doi: 10.1007/978-1-61779-953-2_34.

Cesta, M. F. (2006): Normal structure, function, and histology of the spleen. Toxicol Pathol. ;34:455-465.

Chokkalingam, V.; Tel, J.; Wimmers, F.; Liu, X.; Semenov, S.; Thiele, J.; Figdor, C.G. and Huck WT (2013): "Probing cellular heterogeneity in cytokine- secreting immune cells using droplet-based microfluidics". Lab Chip. 13 (24): 4740-4. doi: 10.1039/c31c50945a.

EL-Sheikh, A. A.; Ameen, S. H. and Ibrahim, H. H. (2016): The immunotoxic effects of short term chronic exposure to titanium dioxide nanoparticles on spleen of adult albino rats and the role of after toxic effect follow up. Ain Shams J Forensic Med Clin Toxicol. 26:115-128.

Golalipour, M. J.; Kord, H.; Ghafari, S.; Gharravi, A. M.; Davarian, A.; Fazeli, S. A. et al., (2008): Morphometric alterations of the rat spleen following formaldehyde exposure. Folia Morphol (Warsz). 67(1):19-23.

Gomaa, M. S.; Elmesallamy, G. E. and Sameer, M. M. (2012): Evaluation of genotoxic effects of formaldehyde in adult albino rats and its implication in case of human exposure. Life Science Journal,9(4).

Haiyan, W.; Kehong, T.; Rongli, S.; Lihong, Y.; Juan, Z. and Yuepu, P. (2014): Aberrant Production of Th1/Th2/Th17-Related Cytokines in Serum of C57BL/6 Mice after Short-Term Formaldehyde Exposure. Int J Environ Res Public Health.; 11(10): 1003610050. doi: 10.3390/ijerph111010036.

Holladay, S. D.; Smith, B. J. and Gogal, R. M. (2010): Exposure to formaldehyde at therapeutic levels decreases peripheral blood lymphocytes and hematopoietic progenitors in the pronephros of tilapia Oreochromis niloticus. Aquatic Biology, 10(3), 241-247. DOI: 10.3354/ab00282.

Hosgood, H.D.; Zhang, L.; Tang, X.; Vermeulen, R.; Hao, Z.; Shen, M. et al. (2013): Occupational exposure to formaldehyde and alterations in lymphocyte subsets. Amer J Ind Med. ;56:252257. doi: 10.1002/ajim.22088.

Ikeda, H.; Old, L.J. and Schreiber, R. D. (2002): The roles of IFN gamma in protection against tumor development and cancer immunoediting. Cytokine Growth Factor Rev.;13(2):95-109.

Kawanishi, M.; Matsuda, T. and Yagi, T. (2014): Genotoxicity of formaldehyde: molecular basis of DNA damage and mutation. Front. Environ. Sci., | https://doi.org/10.3389/fenvs.2014.00036.

Kim, K.H.; Jahan, S.A. and Lee, J.T. (2011): Exposure to formaldehyde and its potential human health hazards. J Environ Sci

Health C Environ Carcinog Ecotoxicol Rev.;29: 277-99. doi: 10.1080/10590501.2011.629972. 
Li, Q.; Mei, Q.; Huyan, T., Xie, L.; Che, S. et al. (2013): Effects of formaldehyde exposure on human NK cells in vitro. Environ Toxicol Pharmacol 36: 948-955. doi: 10.1016/j.etap.2013.08.005.

Monfared, A. L.; Naward, S. H.; Bahrami, A. M. and Hosseini, E. (2013): Histologic and histometric assessments of the potential formaldehyd immunotoxicity. European Journal of Experimental Biology, 3(1):429-433.

Ohtsuka, R.; Shutoh, Y.; Fujie, H.; Yamaguchi, S.; Takeda, M. et al. (2003): Rat strain difference in histology and expression of Th1- and Th2-related cytokines in nasal mucosa after short-term formaldehyde inhalation. Exp Toxicol Pathol 54: 287-291.

Orsiere, T.; Sari-Minodier, L.; Larmarcovai, G and Botta, A. (2006): Genotoxic risk assessment of pathology and anatomy laboratory workers exposed to formaldehyde by use of personal air sampling and analysis of DNA damage in peripheral lymphocytes. Mutat Res.16;605(1-2):30-41.

Pierce, J.S.; Abelmann, A.; Spicer, L.J.; Adams, R.E.; Glynn, M.E.; Neier, K. et al. (2011): Characterization of formaldehyde exposure resulting from the use of four professional hair straightening products. J Occup Environ Hyg. 8(11):686-99. doi: 10.1080/15459624.2011.626259. Raja, D. and Sultana, B. (2012): Potential health hazards for students exposed to formaldehyde in the gross anatomy laboratory. J Environ Health. ;74(6):36-40.

Renwick, A. G. (1989): Pharmaco-kinetics in Toxicology. In principal \&methods: of Toxicology. $2^{\text {nd }}$ ed. Hayes WZ Avoreu Press: pp 764.

Salthammer, T.; Mentese, S.; and Marutzky, R. (2010): Formaldehyde in the indoor environment. Chem. Rev. 110(4):2536-2572. doi.org/10.1021/cr800399g.

Sasaki Y.; Ohtani T.; Ito Y.; Mizuashi M.; Nakagawa S.; Furukawa T.; Horii A. and Aiba, S. (2009): Molecular events in human T cells treated with diesel exhaust particles or formaldehyde that underlie their diminished interferon-gamma and interleukin-10 production. Int. Arch. Allergy Immunol. ;148:239-250. doi: 10.1159/000161584.

Shahadat, H.; Samiul, I.; Subrata, B. and Abu Shara Shamsur R. (2016): Investigation of Formaldehyde Content in Dairy Products Available in Bangladesh by a Validated High Performance Liquid Chromatographic Method. Dhaka Univ. J. Pharm. Sci. 15(2): 187-194. doi.org/10.3329/dujps.v15i2.30936.
Shankar, S. and Genhong, C. (2012): Role of Interleukin 10 Transcriptional Regulation in Inflammation and Autoimmune Disease. Crit Rev Immunol.;32(1): 23-63.

Singh, N. P.; Mc Coy, M. T., Tice, R.R. R. and Schneider, E. L. (1988): A simple technique for quantitation of low levels of DNA damage in individual cells. Exp. Cell Res., 175: 184-191.

Starr, T.K.; Jameson, S.C. and Hogquist, K.A. (2003): "Positive and negative selection of $\mathrm{T}$ cells". Annual Review of Immunology. 21 (1): 139176.

Steven, M. L.; Adam, W. and Stephanie, C. F. (2019): Structure-function of the immune system in the spleen. Sci Immunol. 2019 Mar 1; 4(33): eaau6085. doi: 10.1126/sciimmunol.aau6085.

Suvarna, S. K.; Layton, C.; Bancroft, J. D. (2013) : Bancroft's theory and practice of histological techniques. 7th ed. London: Churchill Livingstone. Tsuchiya, K.; Hayashi, Y.; Onodera, M. and Hasegawa, T. (1975): Toxicity of formaldehyde in experimental animalsconcentrations of the chemical in the elution from dishes of formaldehyde resin in some vegetables. Keio J. Med., 24, pp. 19-37.

Vargova, M.; Wagnerova, J.; Liskova, A.; Jakubovsky, J.; Gajdova, M.; Stolcova, E. et al. (1993): Subacute immunotoxicity study of formaldehyde in male rats. Drug Chem Toxicol. ;16(3):255-75.

World Health Organization (WHO)(1996): Guidelines for drinking-water quality, 2nd ed. Vol.2. Health criteria and other supporting information, Geneva.

Xiaowei J.; Qiang, J.; Zhihu, Z.; Weimin, G.; Xianan Z.; Yong, N., Tao, M. et al. (2014): Effects of Formaldehyde on Lymphocyte Subsets and Cytokines in the Peripheral Blood of Exposed Workers. PLOS ONE | www.plosone.org, Volume 9 | Issue 8 | e104069.

Ye, X.; Yan, W.; Xie, H.; Zhao, M. and Ying C (2005): Cytogenetic analysis of nasal mucosa cells and lymphocytes from high-level long-term formaldehyde exposed workers and low-level shortterm exposed waiters. Mutat Res 588: 22-27.

Zhang, L.; Tang, X.; Rothman, N.; Vermeulen, R.; Ji, Z.; Shen, M.; et al. (2010): Occupational exposure to formaldehyde, hematotoxicity, and leukemia-specific chromosome changes in cultured myeloid progenitor cells. Cancer Epidemiol. Biomark. Prev. ;19:80-88. 


\section{الآثار السامة للفورمالايهايد علي المناعة الخلوية والعلاقة المحتملة لخطر الاصابه بالسرطان: دراسة تجريبية}

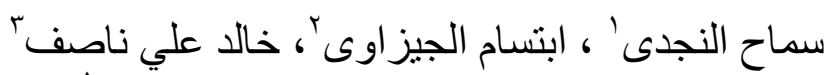

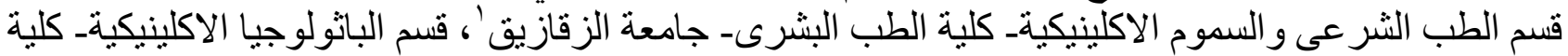

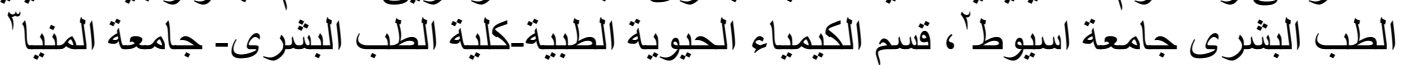

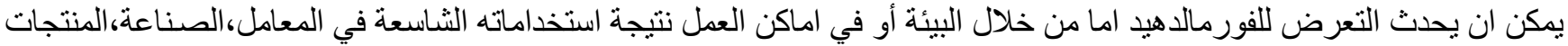

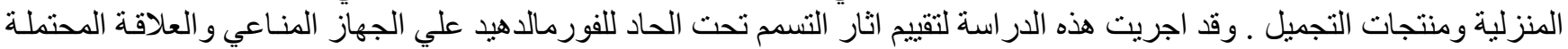

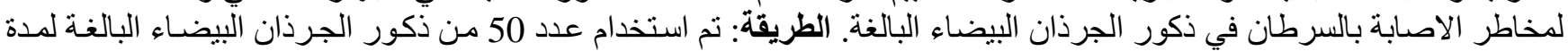

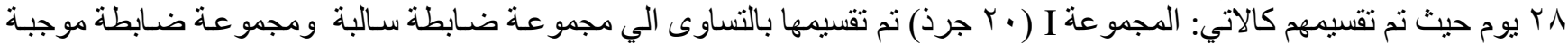

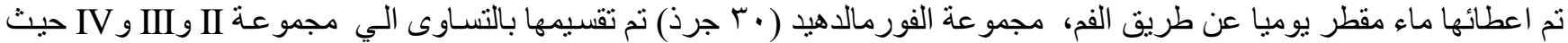

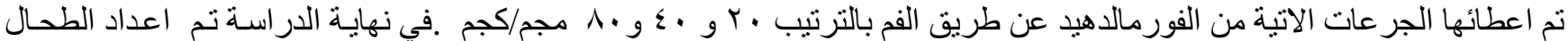

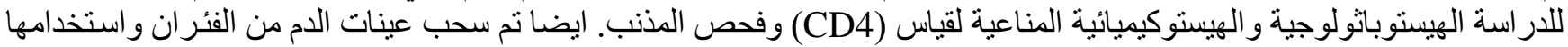

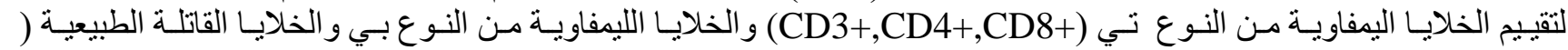

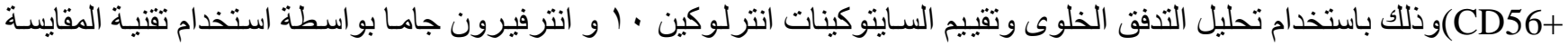

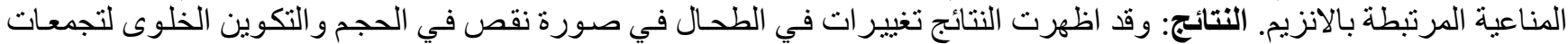

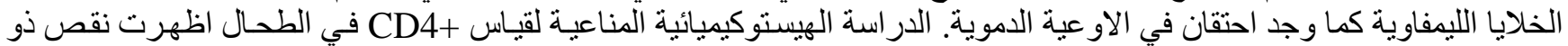

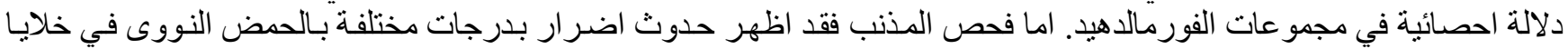

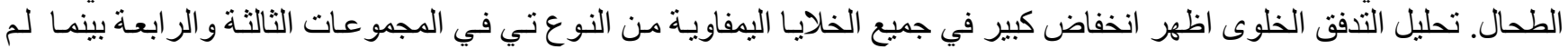

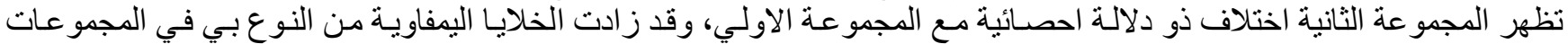

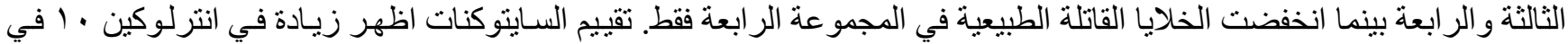

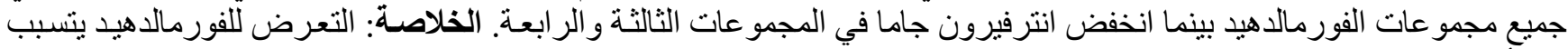

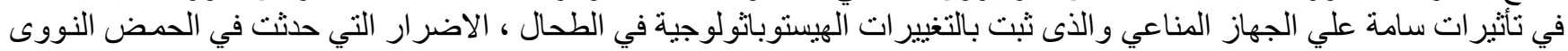

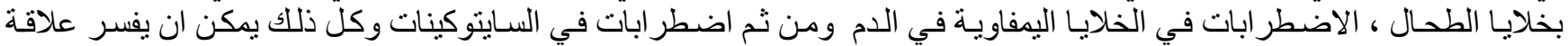

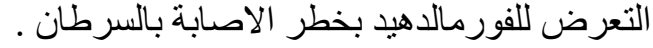

